\title{
Evektivitas program keluarga harapan dalam meningkatkan kesejahteraan masyarakat
}

\author{
Domri Domri $^{1^{*}}$, Ridwan Ridwan ${ }^{2}$, Mulia Jaya ${ }^{3}$ \\ ${ }^{123}$ Fakultas Ilmu Sosial dan Ilmu Politik, Universitas Muara Bungo \\ *Korespondensi Penulis
}

\section{Informasi Artikel}

Abstrak

\section{Kata Kunci : \\ Program Keluarga Harapan \\ Kesejahteraan Masyarakat \\ Pemerintahan Desa}

Histori Artikel :
Kesejahteraan masyarakat merupakan tolok ukur perkembangan suatu bangsa. Tingkat kesehatan, pendidikan, perekonomian perlu diperhatikan. Program Harapan Keluarga yang dicanangkan oleh pemerintah mempunyai pengaruh terhadap kesejahteraan masyarakat. Penelitian ini bertujuan untuk menganalisis bagaimana efektivitas Program Keluarga Harapan dalam meningkatkan kesejahteraan masyarakat di Desa Pulau Lebar Kecamatan Tabir Barat Kabupaten Bungo. Penelitian ini merupakan penelitian deskriptif kualitatif. Hasil penelitian menunjukkan bahwa Program PKH efektif dalam meningkatkan kesejahteraan masyarakat, dimana PKH adalah membantu mengurangi kemiskinan dengan cara meningkatkan kualitas sumber daya manusia pada kelompok masyarakat sangat miskin. Sedangkan hambatannya adalah rendahnya partisipasi masyarakat, kendala teknis dalam proses pendataan penerima program $\mathrm{PKH}$, kendala teknis dalam pendampingan program $\mathrm{PKH}$, serta kendala teknis dalam penyaluran/pendistribusian dan penggunaan dana program PKH. Adapun upaya Pemerintah Desa Pulau Lebar Kecamatan Tabir Barat dalam mengatasi hambatan pada program PKH dalam meningkatkan kesejahteraan masyarakat diantaranya; meningkatkan sosialisasi, pemutakhiran data penerima $\mathrm{PKH}$, kepastian jadwal pembayaran, penangguhan atau pembatalan peserta.

Copyright (C) 2019 Jurnal Politik dan Pemerintahan Daerah 


\section{Pendahuluan}

Dalam rangka percepatan penanggulangan kemiskinan sekaligus pengembangan kebijakan dibidang perlindungan sosial, tahun 2007 Pemerintah Indonesia telah meluncurkan Program Keluarga Harapan (PKH). Program bantuan tunai bersyarat atau disebut dengan Conditional Cash Trasfers (CCT), telah dilaksanakan dibeberapa negara dan cukup berhasil dalam menanggulangi kemiskinan yang dihadapi negara-negara tersebut. Program Keluarga Harapan (PKH) yang sudah berlangsung selama ini dalam rangka membantu rumah tangga sangat miskin mempertahankan daya beli pada saat pemerintah melakukan penyusuian harga BBM. Program Keluarga Harapan (PKH) lebih dimaksudkan sebagai upaya membangun sistem perlindungan sosial pada masyarakat miskin dalam ranggka mempertahankan dan meningkatkan kesejahteraan sosial penduduk miskin sekaligus upaya memotong rantai kemiskinan yang terjadi selama ini.

Dengan PKH diharapkan Perserta PKH (selajutnya disebut Rumah Tangga/Keluarga Sangat Miskin (RTSM/KSM) memiliki akses yang sangat baik untuk memanfaatkan pelayanan sosial dasar, yaitu kesehatan, pendidikan, pangan dan gizi, termasuk menghilangkan kesenjangan sosial, ketidak berdayaan dan keterasingan sosial yang selama ini melekat pada diri masyarakat miskin. Peserta PKH memiliki berbagai kewajiban yang harus dipenuhi khususnya kewajiban yang dibidang kesehatan dan pendidikan. Kewajiban dibidang kesehatan berkaitan dengan pemeriksaan kandungan bagi ibu hamil, pemeriksaan kesehatan, pemberian asupan gizi dan imunisasi anak balita. Di bidang pendidikan kewajiban peserta PKH terkait dengan menyekolahkan anak kesekolah dasar dan lanjutan (SD s.d SLTP/SMP).

PKH akan memberikan manfaat jangka pendek dan jangka panjang. Untuk jangka pendek, PKH akan memberikan income effect kepada RTSM/KSM melalui pengurangan beban pengeluaran rumah tangga. Untuk jangka panjang, program ini diharapkan mampu memutus rantai kemiskinan antar generasi melalui peningkatan kualitas kesehatan/nutrisi, pendidikan dan kapasitas pendapatan anak dimasa depan (serta memberikan kepastian kepada si anak akan masa depannya. Secara faktual dan menurut teori yang ada, tingkat kemiskinan suatu rumah tangga secara umum terkait dengan tingkat kesehatan dan pendidikan. Rendahnya penghasilan keluarga sangat miskin menyebabkan keluarga tersebut tidak mampu memenuhi kebutuhan kesehatan dan pendidikan, untuk tingkat minimal sekalipun.

Menurut BPS masih terdapat banyak anak usia sekolah yang tidak berada dalam sistem sekolah. Untuk meningkatkan tingkat pasrtisipasi anak dalam sekolah maka keikutsertaan mereka yang berada diluar sistem sekolah harus di tingkatkan. Sebagian besar dari mereka yang tidak berada dalam sistem sekolah biasanya berkerja untuk membantu kehidupan keluarga. PKH merupakan salah satu program penangulangan kemiskinan yang melibatkan beberapa sektor yang dalamnya memerlukan kontribusi dan komitmen lembaga/istansi terkait yang meliputi: Kementerian Kesehatan, Kementerian Pendidikan dan Kebudayaan, Kementerian Agama, BPS, dan PT Pos Indonesia dan lembaga Keuangan perbankan dalam penyaluran bantuan bagi peserta PKH. Peran Pemerintahan Derah (pemda) dalam memastikan kesediaan sarana dan prasarana fasilitas kesehatan pendidikan sangat dibutukkan untuk kelancaran pelaksanaan PKH ini sesuai komitmen yang sudah ditandatangani oleh masing-masing kepala daerah.

Berdasarkan hasil penelitian Lidiana tentang pengaruh dan efektifitas bantuan Program Keluarga Harapan (PKH) terhadap partisipasi pendidikan di Kecamatan Muara Tiga Kabupaten Pidie, diketahui bahwa rata-rata tingkat efektifitas pemberian bantuan PKH dari tahun 2008-2013 mencapai 95,58 persen. Bantuan PKH mampu menjelaskan atau mempengaruhi partisipasi pendidikan anak - anak RTSM di Kecamatan Muara Tiga Kabupaten Pidie mencapai 96,8 persen dan sisanya sebesar 3,2 persen di pengaruhi oleh variabel lainnya diluar model penelitian ini.

Puslitbangkesos Kementerian Sosial telah melakukan penelitian pada tujuh provinsi di Indonesia tentang dampak pada rumah tangga sangat miskin. Penelitian yang dibukukan ini bertujuan untuk mengetahui dampak pelaksanaan Program Keluarga Harapan ( $\mathrm{PKH}$ ) di tujuh provinsi serta merumuskan peluang pengembangan PKH di Indonesia. Hasil penelitian menunjukkan bahwa secara umum, kondisi RTSM pasca PKH lebih baik daripada kondisinya sebelum PKH, meskipun di beberapa provinsi justru mengalami penurunan status sosial ekonomi dan penurunan ketangguhan (resiliensi) Rumah Tangga Sangat Miskin (RTSM). 
Hasil penelitian Antriya Eka Suwinta tentang implementasi Program Keluarga Harapan (PKH) di Desa Maron Kecamatan Kademangan Kabupaten Blitar menunjukkan bahwa implementasi PKH di Desa Maron Kecamatan Kademangan Kabupaten Blitar kurang berhasil. Hal ini dikarenakan walaupun serangkaian tahapan yang berjalan dengan lancar, sumberdaya yang dimiliki meliputi staf, kewenangan, informasi dan fasilitas maupun kemampuan pelaksana (disposisi) PKH di Desa Maron juga telah memberikan kontribusi pada pelaksanaan PKH dan para pelaksana di Desa Maron juga telah menjalankan tugas sesuai dengan Standard Operational Procedures (SOP's) serta melakukan pembagian tata kerjanya dengan baik.

Berdasarkan observasi awal peneliti di Desa Pulau Lebar Kecamatan Tabir Barat Kabupaten Merangin diketahui bahwa program PKH telah mampu mendorong masyarakat yang berada pada kategori RTSM/KSM untuk meningkatkan kesejahteraan mereka melalui perubahan pola hidup dan perilaku yang menyangkut pendidikan dan perbaikan kesehatan, dengan pendidikan yang memadai diharapkan keluarga sangat miskin mampu keluar dari jeratan kemiskinan serta dengan kondisi kesehatan yang baik RTSM/KSM dapat bekerja dan menghasilkan pendapatan yang memadai sehingga pada akhirnya mampu meningkatkan kesejahteraan mereka. Dengan jumlah penerima manfaat sebanyak 42 orang, berikut rinciannya:

Tabel 1.1

Daftar Penerima Manfaat Program PKH Desa Desa Pulau Lebar Kecamatan Tabir Barat Tahun 2017

\begin{tabular}{cclc}
\hline No & Rincian & Jumlah & Keterangan \\
\hline 1 & Ibu Hamil & 6 orang \\
2 & Balita & 8 orang \\
3 & Siswa Sekolah (SD/SMP) & 28 orang \\
& Total & 42 orang \\
\hline
\end{tabular}

Sumber : Pendamping PKH Kecamatan Tabir Barat, 2017

Dalam pelaksanaan program PKH di Desa Pulau Lebar Kecamatan Tabir Barat Kabupaten Merangin, peneliti juga menemukan beberapa permasalahan yang menjadi kendala dalam upaya pemerintah untuk meningkatkan kesejahteraan masyarakat, permasalahan yang sangat krusial yaitu masih ada penerima program PKH yang tidak tepat sasaran, dimana penerima program PKH diberikan kepada orang yang mampu dan ada juga penerima program PKH yang merupakan usia lanjut, padahal tujuan utama PKH adalah membantu mengurangi kemiskinan dengan cara meningkatkan kualitas sumber daya manusia pada kelompok masyarakat sangat miskin. Dalam jangka pendek, bantuan ini membantu mengurangi beban pengeluaran RTSM, sedangkan untuk jangka panjang, dengan mensyaratkan keluarga penerima untuk menyekolahkan anaknya, melakukan imunisasi balita, memeriksakan kandungan bagi ibu hamil, dan perbaikan gizi, diharapkan akan memutus rantai kemiskinan antar generasi.

Selain itu peneliti juga mendapatkan keluhan dari penerima program $\mathrm{PKH}$ mengenai proses pencairan yang mengharuskan melalui kantor POS, berhubungan Kantor POS hanya ada di Pasar Rantau Panjang Kecamatan Tabir, maka penerima program PKH diharuskan mengambil dana tersebut di Kantor POS Pasar Rantau Panjang yang jarak tempuhnya mencapai 48 km dengan menghabiskan waktu perjalanan 2 jam menggunakan kendaraan umum, dikarenakan kondisi jalan yang kurang baik. 
Terkadang mereka harus menginap dikarenakan mengantri terlalu lama sehingga tidak cukup waktu untuk pulang.

Permasalahan lainnya yang peneliti temukan adalah kurangnya peran pendamping PKH dalam meningkatkan kesejahteraan masyarakat di Desa Pulau Lebar Kecamatan Tabir, hal ini terlihat dari kurangnya pendampingan yang diberikan, pendamping hanya terlihat pada saat pendataan dan pemberian informasi ketika dana cair, namun kurang dalam pendampingan rutin. Padahal setiap RTSM yang menerima dana bantuan didampingi oleh pendamping dalam pengalokasian dana yang telah didapatkan agar tepat pada sasaran yaitu untuk pendidikan dan kesehatan. Peran pendamping PKH menjadi sangat penting karena mayoritas Penerima dana PKH merupakan RTSM yang memiliki tingkat pendidikan yang rendah sehingga membutuhkan fasilitas pendampingan. Proses pendampingan yang dilakukan oleh pendamping PKH merupakan agenda rutin yang harus dilakukan sebagai upaya mengarahkan RTSM agar tepat dalam penggunaan dana bantuan tersebut. Berdasarkan permasalahan yang diungkapkan di atas, maka peneliti tertarik untuk melakukan kajian lebih lanjut dalam bentuk karya ilmiah yang peneliti tuangkan pada proposal yang berjudul "Efektivitas Program Keluarga Harapan Dalam Meningkatkan Kesejahteraan Masyarakat Desa Pulau Lebar Kecamatan Tabir Barat"

\section{Metode}

Jenis penelitian yang dilalukan penulis pada penelitian ini adalah jenis penelitian Deskriptif Kualitatif yaitu menggambarkan dan menjelaskan bagaimana keadaan dari objek penelitian berdasarkan fakta-fakta yang ada serta menganalisanya agar bisa menarik suatu kesimpulan.

\section{Teknik Pengumpulan Data}

Untuk memperoleh data yang akurat, relevan, dan dapat di pertanggung jawabkan maka penulis mengunakan beberapa teknik dalam pengumpulan data karena masing masing mempunyai kelebihan dan kekurangan, teknik pengumpulan data dalam penelitian ini, yaitu:

a. Observasi, yaitu pengumpulan data dengan cara mengadakan pengamatan langsung terhadap kegiatan Program Keluarga Harapan di Desa dalam melaksanakan tugas pendampingan.

b. Wawancara (Interview), yaitu teknik pengumpulan data dimana peneliti secara langsung mengadakan tanya jawab dengan informan yang telah ditentukan.

c. Dokumentasi, Dokumentasi adalah informasi yang berasal dari catatan penting baik dari lembaga atau organisasi maupun dari perorangan. Dokumentasi penelitian ini merupakan pengambilan gambar oleh peneliti untuk memperkuat hasil penelitian. Dokumentasi bisa berbentuk tulisan, gambar atau karya-karya monumental dari seseorang. Dalam penelitian ini dokumen yang digunakan adalah, undang-undang dan media informasi lain yang ada hubungannnya dengan Program Keluarga Harapan

\section{Jenis Data}

Data yang dikumpulkan dalam penelitian ini dibedakan menjadi dua yakni:

1. Data primer, yang dikumpulkan berbentuk hasil wawancara yang dilakukan terhadap narasumber yang berasal dari para pelaku yang terkait dengan pelaksanaan Program Keluarga Harapan dalam meningkatkan kesejateraan masyarakat desa di Desa Pulau Lebar Kecamatan Tabir Barat Kabupaten Merangin

2. Data Sekunder, data ini diperlukan untuk mendukung analisis dan pembahasan yang maksimal. Data sekunder juga diperlukan terkait pengungkapan fenomena sosial dalam penelitian ini. Data sekunder ini antara lain, kepustakaan (Library Research) serta bahan dari internet.

\section{Penentuan Informan}

Mengingat data yang diperlukan adalah program PKH dalam mensejahterakan masyarakat maka pemilihan informan dalam penelitian ini adalah dengan metode purposive sampling (teknik penentuan sampel dengan pertimbangan tertentu) karena dalam teknik proporsive sampling ini teknik penarikan sample secara subjektif dengan maksud atau tujuan tertentu yang mana 
Vol 1, No 1, Juni 2019, pp. 1-16

menganggap bahwa informan yang diambil tersebut memiliki informasi yang diperlukan bagi penelitian yang akan dilakukan.

Adapun informan dalam penelitian ini adalah sebagai berikut :

Tabel 3.1

Daftar Informan

\begin{tabular}{lcc}
\hline No & Nama & Jabatan \\
\hline 1 & M. Taher & Kepala Desa Pulau Lebar \\
2 & Wandi & Pendamping PKH Kecamatan Tabir Barat \\
3 & Wilda Hidayat & Sekertaris Desa Pulau Lebar \\
4 & Ali Ahmad & Ketua BPD Pulau Lebar \\
5 & Saihu & Tokoh Masyarakat Pula Lebar \\
6 & Siti Ramlah & RTM Pulau Lebar \\
7 & Mardiana T & RTM Pulau Lebar \\
8 & Rosiah & RTM Pulau Lebar \\
\hline
\end{tabular}

\section{Analisis Data}

Berangkat dari penelitian ini, untuk menganalisis data yang telah dikumpulkan dan diseleksi digunakan teknik analisis data deskriptif-kualitatif, yaitu data-data yang telah dihimpun dan dikumpulkan baik observasi maupun interview (wawancara), selanjutnya disusun, dianalisis, diinterprestasikan untuk kemudian dapat diambil kesimpulan sebagai jawaban atas masalah yang diteliti. Pengambilan kesimpulan dalam penelitian ini dilakukan secara induktif yaitu dari data dan fakta yang khusus, peristiwa-peristiwa yang kongkrit, kemudian dari fakta atau peristiwa yang khusus itu dianalisis ketingkat abstrak yang lebih tinggi.

\section{Hasil dan Pembahasan}

Bantuan yang disalurkan kepada peserta PKH bersumber dari APBN, dan untuk kelancaran pelaksanaan di Kabupaten Kota diperlukan dukungan APBD untuk kelancaran kegiatan dan Pelaksanaan PKH. Pelaksanaan program keluarga harapan (PKH) hingga tahun 2015 diharapkan dapat menjadi sebuah solusi dalam upaya memutus rantai kemiskinan bagi RTSM dimana kepesertaan PKH tidak hanya dapat memberikan manfaat bagi masyarakat penerima PKH saja, tetapi perubahan pola hidup dan perilaku yang menyangkut pendidikan dan perbaikan kesehatan dapat berdampak luas kepada masyarakat di wilayah dilaksanakannya program PKH. Dalam pelaksanaannya peserta yang menerima dana PKH akan menerima bantuan selama maksimal enam tahun. kualitas hidupnya.

Faktor penting penunjang berjalannya program yaitu peran dari tim pendamping PKH. Dalam pelaksanaannya setiap RTSM yang menerima dana bantuan didampingi oleh pendamping dalam pengalokasian dana yang telah didapatkan agar tepat pada sasaran yaitu untuk pendidikan dan kesehatan. Peran pendamping PKH menjadi sangat penting karena mayoritas Penerima dana PKH merupakan RTSM yang memiliki tingkat pendidikan yang rendah sehingga membutuhkan fasilitas pendampingan. Proses pendampingan yang dilakukan oleh pendamping PKH merupakan agenda rutin yang harus dilakukan sebagai upaya mengarahkan RTSM agar tepat dalam penggunaan dana bantuan tersebut. 
Peraturan Menteri Sosial Nomor 1 Tahun 2018 tentang Program Keluarga Harapan Pasal 2 menjelaskan bahwa PKH bertujuan: untuk meningkatkan taraf hidup Keluarga Penerima Manfaat melalui akses layanan pendidikan, kesehatan, dan kesejahteraan sosial, mengurangi beban pengeluaran dan meningkatkan pendapatan keluarga miskin dan rentan, menciptakan perubahan perilaku dan kemandirian Keluarga Penerima Manfaat dalam mengakses layanan kesehatan dan pendidikan serta kesejahteraan sosial, mengurangi kemiskinan dan kesenjangan; dan mengenalkan manfaat produk dan jasa keuangan formal kepada Keluarga Penerima Manfaat.

Tujuan utama PKH Kesehatan adalah meningkatkan status kesehatan ibu dan anak di Indonesia, khususnya bagi kelompok masyarakat sangat miskin, melalui pemberian insentif untuk melakukan kunjungan kesehatan yang bersifat preventif (pencegahan, dan bukan pengobatan). Seluruh peserta PKH merupakan penerima jasa kesehatan gratis yang disediakan oleh program Askeskin dan program lain yang diperuntukkan bagi orang tidak mampu. Kartu PKH bisa digunakan sebagai alat identitas untuk memperoleh pelayanan tersebut. Komponen pendidikan dalam PKH dikembangkan untuk meningkatkan angka partisipasi pendidikan dasar wajib 9 tahun serta upaya mengurangi angka pekerja anak pada keluarga yang sangat miskin. Anak penerima PKH Pendidikan yang berusia 7-18 tahun dan belum menyelesaikan program pendidikan dasar 9 tahun harus mendaftarkan diri di sekolah formal atau non formal serta hadir sekurang-kurangnya $85 \%$ waktu tatap muka. Setiap anak peserta PKH berhak menerima bantuan selain PKH, baik itu program nasional maupun lokal. Bantuan PKH bukanlah pengganti program-program lainnya karenanya tidak cukup membantu pengeluaran lainnya seperti seragam, buku dan sebagainya. PKH merupakan bantuan agar orang tua dapat melanjutkan pendidikan keseluruh dalam rangka untuk melanjutkan pendidikan anak.

Dengan demikian terlihat bahwa 28 orang penerima manfaat merupakan keluarga yang memiliki anak usia sekolah, sedangkan 8 orang penerima program PKH merupakan anak balita, sisanya sebanyak 6 orang merupakan ibu hamil. Jumlah tersebut tidak menggambarkan kondisi masyarakat di Desa Pulau Lebar, Padahal masih ada masyarakat yang sangat membutuhkan bantuan tersebut. Batuan PKH seharusnya bisa membantu masyarakat yang sangat membutuhkan sehingga mereka benar-benar bisa tertolong dari kemiskinan. Sehingga anak-anak mereka bisa melanjutkan sekolah.

1. Meningkatkan Kualitas Kesehatan Rumah Tangga Miskin/Keluarga Sangat Miskin (RTM/ KSM).

Kesehatan bagi Rumah Tangga Miskin yang sudah ditetapkan menjadi peserta PKH dan memiliki kartu PKH diwajibkan memenuhi persyaratan kesehatan yang sudah ditetapkan dalam protokol pelayanan. Untuk mengetahui gambaran tentang Program Keluarga Harapan (PKH) telah berjalan dengan prosedurnya di Desa Pulau Lebar Kecamatan Tabir Barat Kabupaten Merangin dapat dilihat tingginya kesadaran masyarakat untuk memperoleh kesehatan dan peduli terhadap perilaku hidup sehat, hal ini sebagaimana disampaikan oleh Bapak M. Taher selaku Kepala Desa Pulau Lebar, berikut penuturannya:

“...semenjak adanya program PKH bagi masyarakat miskin terjadi peningkatan kesehatan masyarakat, banyak masyarakat telah peduli terhadap kesehatan mereka, karena mereka selalu mendapatkan pendampingan dari petugas, dengan adanya program $\mathrm{PKH}$ yang diintegrasikan dengan kartu Indonesia Sehat, banyak masyarakat yang mendatangi puskesmas untuk berobat..."

Pendapat yang sama juga disampaikan oleh Bapak Wandi selaku Pendamping PKH Kecamatan Tabir Barat:

“...dengan adanya program PKH masyarakat miskin dapat berobat secepat mungkin tanpa harus menunggu sakitnya menjadi lebih parah, hal ini dikarenakan program PKH diperuntukan bagi rumah tangga miskin yang masih usia produktif, dengan mereka selalu dalam keadaan sehat diharapkan mereka dapat bekerja dengan baik yang pada akhirnya akan meningkatkan taraf hidup mereka..." 
Vol 1, No 1, Juni 2019, pp. 1-16

Kondisi tersebut dibenarkan oleh Ibu Siti Ramlah selaku RTM Pulau Lebar:

“...kami bersyukur sekali dapat ikut program PKH, dengan adanya program PKH kami mendapatkan bimbingan dari petugas untuk peduli kesehatan dan segera berobat ketika sakit, sebab program PKH memberikan uang secara tunai, jika sakitnya parah maka kita bisa berobat ke puskesmas menggunakan Kartu Indonesia Sehat.."

Apa yang disampaikan oleh informan berkesesuaian dengan hasil pengamatan di Posyandu Desa Pulau Lebar dan Puskesmas Muara Kibul, dimana peneliti banyak menemukan ibuibu yang memeriksa kesehatan mereka dan anak mereka.

\section{Meningkatkan Taraf Pendidikan Anak-Anak RTM/KSM}

Pendidikan dan kapasitas pendapatan anak dimasa depan (price effect anak keluarga miskin memberikan kepastian kepada sianak akan masa depannya (insurance effect). Untuk mengetahui gambaran tentang Program Keluarga Harapan (PKH) membantu pendidikan bagi anak-anak dalam rumah tangga miskin/keluarga sangat miskin (RTSM/KSM) di Desa Pulau Lebar Kecamatan Tabir Barat Kabupaten Merangin terlihat dari tingginya angka partisipasi sekolah anak usia sekolah di Desa Pulau Lebar Kecamatan Tabir Barat Kabupaten Merangin, hal ini sebagaimana disampaikan oleh Bapak M. Taher selaku Kepala Desa Pulau Lebar,

“...Alhamdulillah semenjak bergulirnya program PKH di Desa Pulau Lebar, masyarakat miskin sangat merasakan dampaknya terhadap peningkatan pendidikan anak, sekarang banyak anak usia sekolah yang bersekolah tanpa harus terbebani seragam sekolah, karena ada uang untuk beli baju seragam..."

Selanjutnya beliau menambahkan:

“....memang di sekolah ada program dana BOS, hanya saja tidak untuk seragam sekolah anak, dengan anaknya uang tunai yang diterima orang tua melalui program PKH dimungkinkan untuk membeli kebutuhan siswa seperti buku sekolah maupun seragam sekolah..."

Pendapat yang sama juga disampaikan oleh Bapak Ali Ahmad selaku Ketua BPD Pulau Lebar, berikut penuturannya:

“...terima kasih kami ucapkan pada pemerintah yang peduli terhadap masyarakat miskin, khususnya bagi pendidikan anak, dengan adanya program PKH banyak sudah anak yang bersekolah, kalau dulu selalu biaya sekolah dijadikan alasan, padahal sekolah sudah gratis, dengan adanya PKH orang tua mampu untuk membeli buku serta keperluan sekolah anak...."

Manfaat dari Program PKH juga dirasakan oleh Ibu Mardiana T selaku RTM Pulau Lebar yang mendapat program $\mathrm{PKH}$, berikut penjelasannya:

"....Alhamdulillah kami sangat bersyukur mendapatkan bantuan PKH ini, sekarang kami bisa menyekolahkan anak kami hingga tingkat SMP, anak saya ada dua, yang satu masih SD yang satunya lagi sudah SMP.... 
Vol 1, No 1, Juni 2019, pp. 1-16

PKH ini telah memberikan kemudahan pada keluarga miskin untuk menyekolahkan anaknya, meskipun pada kenyataannya belum memberikan perubahan penghidupan kepada keluarga miskin tersebut. Sebagai salah satu contoh dalam upaya untuk menyekolahkan anak, keluarga miskin mampu untuk membayar biaya sekolah namun tidak mampu untuk memberikan uang jajan maupun menempuh jarak sekolah yang cukup jauh dari tempat tinggal. Hal ini sebagaimana disampaikan oleh Bapak Ali Ahmad selaku Ketua BPD Pulau Lebar, berikut penuturannya:

“......PKH ini bagus untuk membantu masyarakat menyekolahkan anaknya, hanya saja dampaknya tidak secara langsung mampu mengubah kehidupan masyarakat miskin, karena dampaknya baru terasa nanti saat anak mereka selesai sekolah, dengan pendidikan yang memadai diharapkan mereka mampu mandiri...."

Selanjutnya beliau menambahkan:

“..hanya saja program PKH ini belum mampu memenuhi kebutuhan anak secara keseluruhan, sebab anak tidak hanya butuh perlengkapan sekolah namun juga uang jajannya, termasuk untuk transportasinya, di sini kan sekolah SMP nya jauh, kalau anak bawa motor belum bisa, terpaksa diantar dan dijemput, tentunya butuh biaya besar..."

PKH diharapkan sebagai program yang mampu memutus rantai kemiskinan antar generasi khususnya di Desa Pulau Lebar Kecamatan Tabir Barat. Program pengentasan kemiskinan melalui Program PKH ini mengarah pada outcome atau hasil dari kegiatan pengentasan kemiskinan yang selama ini telah dilaksanakan dari output atau keluaran yang akan di dapatkan output dari pengentasan kemiskinan ini memang hasilnya tidak secara langsung melainkan memerlukan waktu jangka panjang. Outcome yang diharapkan dari program ini adalah perubahan pola pikir masyarakat (RTSM) tentang pentingnya pendidikan dan kesehatan anak-anak mereka yang nantinya akan mencapai kesejahtraan masyarakat yang terjadi dalam kegiatan Program Keluarga Harapan (PKH) di Desa Pulau Lebar Kecamatan Tabir Barat sesuai konsep Implementasi merupakan proses untuk memastikan terlaksananya suatu kebijakan dan tercapainya kebijakan tersebut.

Menurut Howlett dan Ramesh (dalam Suharto) mengatakan bahwa, implementasi kebijakan sangat dipengaruhi oleh hakekat dan perumusan masalah kebijakan itu, keragaman masalah yang ditangani oleh pemerintah, ukuran kelompok-kelompok sasaran, dan tingkat perubahan perilaku yang diharapkan. Implementasi kebijakan menurut Howlett dan Ramesh sebagai "proses dimana program atau kebijakan itu dilaksanakan; hal ini menunjukkan perubahan rencana menjadi praktek".

Hal senada juga diungkapkan oleh Mazmanian dan Sabitier yang berpendapat bahwa peran penting analis implementasi kebijaksanaan Negara ialah mengidentifikasikan variablevariabel yang mempengaruhi tercapainya tujuan-tujuan formal pada seluruh proses implementasi. Variabel-variabel yang dimaksud antara lain: (1) Mudah tidaknya masalah yang digarap dikendalikan; (2) Kemampuan keputusan kebijaksanaan untuk menstrukturkan secara tepat proses implementasinya; dan (3) Pengaruh langsung perbagai variable politik terhadap keseimbangan dukungan bagi tujuan yang termuat dalam keputusan kebijaksanaan tersebut. 


\section{Hambatan Program PKH dalam Meningkatkan Kesejahteraan Masyarakat Desa Pulau Lebar Kecamatan Tabir Barat}

Berdasarkan hasil wawancara dengan beberapa informan diketahui bahwa terdapat hambatan program PKH dalam meningkatkan kesejahteraan masyarakat Desa Pulau Lebar Kecamatan Tabir Barat, diantaranya adalah:

1. Rendahnya Partisipasi Masyarakat

Jika disebut sebagai program pengentasan kemiskinan, Program Keluarga Harapan (PKH)

merupakan model yang tidak melibatkan partisipasi masyarakat secara. Meskipun terdapat pendamping dan beberapa kegiatan peningkatan kapasitas masyarakat, Program ini bersifat top

down, di mana program dilakukan langsung ditentukan oleh pemerintah dan masyarakat tidak dilibatkan sesuai dengan kapasitas yang mereka miliki. Padahal sebenarnya seberapapun miskinnya kondisi masyarakat tersebut, mereka memiliki kapasitas yang mampu dikembangkan. Sehingga selayaknya masyarakat tidak dipandang berada pada kondisi "gigi nol" atau tidak memiliki potensi apapun. Hal ini sebagaimana disampaikan oleh Bapak Wandi selaku Pendamping PKH Kecamatan Tabir Barat:

“...kendala yang kami rasakan adalah partisipasi masyarakat rendah dalam program $\mathrm{PKH}$, karena mereka merasa ini merupakan program pemerintah, jadi mereka hanya ikut-ikut saja, sehingga tidak ada upaya untuk peningkatakan kualitas hidup, selain itu mereka kurang aktif dalam kegiatan yang kita adakan, termasuk sosialisasi...”

Hal yang sama juga dibenarkan oleh Bapak M. Taher selaku Kepala Desa Pulau Lebar:

“...masyarakat kita ini susah untuk diajak maju dan merubah nasib, ketika ada pencairan mereka baru mau datang, namun ketika ada pendampingan dalam bentuk sosialiasasi mereka tidak mau datang dengan berbagai alasan, padahal pendampingan ini merupakan salah satu upaya meningkatkan pemahaman bagi masyarakat..."

Berdasarkan wawancara di atas, dalam hal pengetahuan dan sosialisasi Program PKH yang dilakukan oleh Petugas PKH Kecamatan Tabir Barat Kabupaten M, terdapat kendala teknis yang menyebabkan sosialisasi tidak maksimal sehingga banyak masyarakat yang belum mengetahui Program PKH. Sosialiasi tidak menjangkau kepada Tokoh Masyarakat, Pejabat Kecamatan dan Kepala Dusun, sehingga pengetahuan mereka sangat minim tentang PKH. Kendalanya diantaranya, keterbatasan dalam mengumpulkan masyarakat dan stakeholders untuk dilakukan sosialisasi oleh petugas PKH di Kecamatan Tabir Barat, dikarenakan jarak tempat tinggal petugas yang jauh dari lokasi pendampingan menyebabkan sulit melakukan pertemuan dengan masyarakat dan stakeholders. Hal ini sebagaimana disampaikan oleh Bapak Wandi selaku Pendamping PKH Kecamatan Tabir Barat:

“...kendala yang kami rasakan dalam sosialisasi adalah sulit sekali mengumpulkan masyarakat, tidak hanya masyarakat namun perangkat desa dan dusun pun susah diajak kumpul, kalau siang alasan mereka menyadap karet atau ke sawah, nanti kalau kita jadwalkan malam alasannya kecapean, dan kitapun susah untuk hadir malam karena lokasinya jauh sekali dari tempat tinggal kita, sehingga kita susah untuk melakukan sosialisasi, ..."

Kemudian, ketersediaan anggaran yang tidak memadai untuk melakukan sosialisasi. Media sosialisasi masih terbatas pada pertemuan secara langsung, karena masyarakat dan penerima PKH belum terbiasa mengakses media lain seperti media sosial dan media brosur lainnya. Sehingga imbasnya, Program PKH belum diketahui secara menyeluruh oleh semua stakeholders masyarakat Kecamatan Tabir Barat. Hal ini sebagaimana disampaikan oleh Bapak Wandi selaku Pendamping PKH Kecamatan Tabir Barat: 
Vol 1, No 1, Juni 2019, pp. 1-16

Kemudian, ketersediaan anggaran yang tidak memadai untuk melakukan sosialisasi. Media sosialisasi masih terbatas pada pertemuan secara langsung, karena masyarakat dan penerima PKH belum terbiasa mengakses media lain seperti media sosial dan media brosur lainnya. Sehingga imbasnya, Program PKH belum diketahui secara menyeluruh oleh semua stakeholders masyarakat Kecamatan Tabir Barat. Hal ini sebagaimana disampaikan oleh Bapak Wandi selaku Pendamping PKH Kecamatan Tabir Barat:

"...ketersedian dana menjadi kendala bagi kita dalam sosialisasi, karena masyarakat kalau kumpul maunya ada makanan, sementara kita tidak ada dana untuk memberikan snack bagi mereka, sehingga banyak sosialisasi yang tidak berjalan, kalau mau pake media sosial susah, karena tidak semua masyarakat menggunakan media sosial, kalau pake brosur juga susah karena jarang dibaca...”

\section{Kendala Teknis Dalam Proses Pendataan Penerima Program PKH}

Dalam proses pendataan penerima untuk menentukan peserta penerima Program PKH di Kecamatan Tabir Barat mengalami berbagai kendala, diantaranya; data yang diambil dari Badan Pusat Statistik dipandang tidak mencerminkan keadaan masyarakat yang sebenarnya. Diindikasikan proses pendataan tidak dilakukan dengan prosedur yang benar, karena masih banyak masyarakat yang seharusnya menjadi peserta $\mathrm{PKH}$, tetapi tidak terdaftar. Hal ini sebagaimana disampaikan oleh Bapak M. Taher selaku Kepala Desa Pulau Lebar:

“...pendataan juga menjadi kendala dalam program PKH, karena banyak masyarakat yang membenar-benar membutuhkan namun tidak terdaftar, kita tidak bisa menyalahkan petugas karena pendataannya dari pusat, ada yang mengatakan kalau perangkat desa bermain, namun kita bantah hal tersebut, tidak benar itu...."

Hal yang berbeda disampaikan oleh Bapak Ali Ahmad selaku Ketua BPD Pulau Lebar:

“....saya kurang paham data penerima PKH itu sumbernya dari mana, namun saya melihat ada kecurangan dari pendataan tersebut, karena banyak yang menerima tersebut merupakan keluarga dari perangkat desa itu sendiri..."

Kondisi tersebut diungkapkan oleh beberapa informan di atas. Selain itu, teridentifikasi bahwa penerima PKH kebanyakan dari keluarga perangkat desa dan kepala dusun, sehingga hal tersebut menimbulkan gejolak dan kecemburuan di masyarakat. Dari fenomena tersebut diperlukan pemutakhiran data, peserta yang menjadi penerima program $\mathrm{PKH}$ mendapatkan sesuai dengan target tujuan program PKH.

\section{Kendala Teknis Dalam Pendampingan Program PKH}

Kendala dalam proses pendampingan $\mathrm{PKH}$ oleh petugas kepada penerima $\mathrm{PKH}$, mengalami berbagai kendala teknis diantarnya; bahwa kendala dari petugas pendamping sendiri yaitu tidak selalu bisa hadir di lokasi pendampingan dikarenakan tempat tinggal pendamping jauh dari lokasi bertugas. Hal tersebut menyulitkan untuk selalu mendampingi peserta PKH di lapangan. Sebagaimana disampaikan oleh Bapak Wandi selaku Pendamping PKH Kecamatan Tabir Barat:

“....Kendala yang kita alami dalam pendampingan adalah lokasi, karena lokasi desa yang satu dengan desa yang lain jauh-jauh, sedangkan tempat tinggal saya jauh dari lokasi, sehingga sulit untuk pendampingan, selain itu kebiasaan masyarakat yang kumpul di malam hari..."

Kemudian, kesulitan pendamping menuju akses wilayah pendampingan karena kondisi jalan yang masih berbatu dan jalan setapak, sehingga sulit untuk mengawasi kondisi penerima PKH. Sebagaimana disampaikan oleh Bapak Wandi selaku Pendamping PKH Kecamatan Tabir Barat:

“....kesulitan yang kami rasakan adalah jalan menuju wilayah pendampingan yang berbatu dan jalan setapak, jadi kalau malam sulit kita mengunjungi penerima PKH, sehingga sulit sekali mengawasi kondisi penerima PKH tersebut..." 
Vol 1, No 1, Juni 2019, pp. 1-16

\begin{abstract}
“...ketersedian dana menjadi kendala bagi kita dalam sosialisasi, karena masyarakat kalau kumpul maunya ada makanan, sementara kita tidak ada dana untuk memberikan snack bagi mereka, sehingga banyak sosialisasi yang tidak berjalan, kalau mau pake media sosial susah, karena tidak semua masyarakat menggunakan media sosial, kalau pake brosur juga susah karena jarang dibaca..."
\end{abstract}

\title{
2. Kendala Teknis Dalam Proses Pendataan Penerima Program PKH
}

Dalam proses pendataan penerima untuk menentukan peserta penerima Program PKH di Kecamatan Tabir Barat mengalami berbagai kendala, diantaranya; data yang diambil dari Badan Pusat Statistik dipandang tidak mencerminkan keadaan masyarakat yang sebenarnya. Diindikasikan proses pendataan tidak dilakukan dengan prosedur yang benar, karena masih banyak masyarakat yang seharusnya menjadi peserta PKH, tetapi tidak terdaftar. Hal ini sebagaimana disampaikan oleh Bapak M. Taher selaku Kepala Desa Pulau Lebar:

“...pendataan juga menjadi kendala dalam program PKH, karena banyak masyarakat yang membenar-benar membutuhkan namun tidak terdaftar, kita tidak bisa menyalahkan petugas karena pendataannya dari pusat, ada yang mengatakan kalau perangkat desa bermain, namun kita bantah hal tersebut, tidak benar itu...."

Hal yang berbeda disampaikan oleh Bapak Ali Ahmad selaku Ketua BPD Pulau Lebar:

"....saya kurang paham data penerima PKH itu sumbernya dari mana, namun saya melihat ada kecurangan dari pendataan tersebut, karena banyak yang menerima tersebut merupakan keluarga dari perangkat desa itu sendiri..."

Kondisi tersebut diungkapkan oleh beberapa informan di atas. Selain itu, teridentifikasi bahwa penerima $\mathrm{PKH}$ kebanyakan dari keluarga perangkat desa dan kepala dusun, sehingga hal tersebut menimbulkan gejolak dan kecemburuan di masyarakat. Dari fenomena tersebut diperlukan pemutakhiran data, peserta yang menjadi penerima program PKH mendapatkan sesuai dengan target tujuan program $\mathrm{PKH}$.

\section{Kendala Teknis Dalam Pendampingan Program PKH}

Kendala dalam proses pendampingan $\mathrm{PKH}$ oleh petugas kepada penerima $\mathrm{PKH}$, mengalami berbagai kendala teknis diantarnya; bahwa kendala dari petugas pendamping sendiri yaitu tidak selalu bisa hadir di lokasi pendampingan dikarenakan tempat tinggal pendamping jauh dari lokasi bertugas. Hal tersebut menyulitkan untuk selalu mendampingi peserta PKH di lapangan. Sebagaimana disampaikan oleh Bapak Wandi selaku Pendamping PKH Kecamatan Tabir Barat:

“....Kendala yang kita alami dalam pendampingan adalah lokasi, karena lokasi desa yang satu dengan desa yang lain jauh-jauh, sedangkan tempat tinggal saya jauh dari lokasi, sehingga sulit untuk pendampingan, selain itu kebiasaan masyarakat yang kumpul di malam hari..."

Kemudian, kesulitan pendamping menuju akses wilayah pendampingan karena kondisi jalan yang masih berbatu dan jalan setapak, sehingga sulit untuk mengawasi kondisi penerima PKH. Sebagaimana disampaikan oleh Bapak Wandi selaku Pendamping PKH Kecamatan Tabir Barat:

“....kesulitan yang kami rasakan adalah jalan menuju wilayah pendampingan yang berbatu dan jalan setapak, jadi kalau malam sulit kita mengunjungi penerima $\mathrm{PKH}$, sehingga sulit sekali mengawasi kondisi penerima PKH tersebut..."

Imbasnya dari kendala di atas dalam proses pendampingan oleh pendamping, tidak bisa memastikan perkembangan dari target tujuan program PKH berjalan dengan baik atau tidak dirasakan oleh peserta PKH. Selain itu, juga Pendamping kurang melakukan koordinasi dengan aparat setempat dan pemberi pelayanan pendidikan dan kesehatan. Kemudian, pertemuan bulanan dengan ketua kelompok dan seluruh peserta PKH juga tidak dilakukan. Petugas PKH otomatis ketika tidak melakukan pendampingan juga tidak memberikan motivasi kepada peserta PKH dalam menjalankan komitmennya. Padahal, dari proses pendampingan tersebut menjadi dasar dalam pemutakhiran data penerima atau peserta PKH selanjutnya, apakah ada kemajuan kesejateraan atau tidak. 
Padahal Peraturan Menteri Sosial Nomor 1 Tahun 2018 tentang Program Keluarga Harapan Pasal 49 mengamanatkan Pendamping sosial bertugas:

a. memastikan Bantuan Sosial PKH diterima oleh Keluarga Penerima Manfaat PKH tepat jumlah dan tepat sasaran;

b. melaksanakan Pertemuan Peningkatan Kemampuan Keluarga bersama Keluarga Penerima Manfaat PKH paling sedikit 1 (satu) kali setiap bulan; dan

c. memfasilitasi Keluarga Penerima Manfaat PKH mendapatkan program bantuan komplementer di bidang kesehatan, pendidikan, subsidi energi, ekonomi, perumahan, dan pemenuhan kebutuhan dasar lain.

\section{Kendala Teknis Dalam Penyaluran/Pendistribusian dan Penggunaan Dana Program PKH}

Kendala teknis dalam proses pendistribusian dana PKH kepada RTSM yang dilakukan oleh Petugas PKH mengalami beberapa kendala, diantaranya yaitu: proses pendistribusian kadang terjadi keterlambatan waktu tidak sesuai jadwal saat pemberian dana kepada peserta PKH, karena kendala sistem jaringan perbankan atau kantor pos setempat. Selain itu, kerap terjadi antrian yang padat saat pembagian dana dilakukan. Maka petugas akhirnya memilih kantor desa atau sekolah-sekolah terdekat yang terjangkau oleh RTSM sebagai tempat berkumpul untuk membagikan dana PKH. Sebagaimana diutarakan oleh Bapak Wandi selaku Pendamping PKH Kecamatan Tabir Barat:

“.....pendistribusian sering terjadi keterlambatan, sehingga masyarakat terbebani oleh biaya tambahan, disinikan bank tidak ada, kantor POS pun jauh di Rantau Panjang, jarak ke Pasar Rantau Panjang lebih kurang 28 km, kalau dilalui dengan menggunakan mobil dengan kondisi jalan yang kurang baik bisa menghabiskan waktu lebih kurang 3 jam, biayanya mencapai 80 ribu rupiah, artinya kalau Bank nya gangguan mereka besok harus datang lagi dengan biaya 80 ribu dikalikan 4 kali perjalanan.."

Dalam hal penggunaan dana PKH oleh peserta PKH sering digunakan tidak sesuai ketentuan peruntukannya. Seharusnya dana PKH digunakan untuk kebutuhan pendidikan anak-anak sekolah dan kesehatan, tetapi sering digunakan untuk kebutuhan lain di luar ketentuan. Dana tersebut ada juga yang digunakan untuk memenuhi kebutuhan sehari-hari orang tua, jika mereka terdesak saat tidak bekerja. Selain itu juga digunakan untuk memperbaiki tempat tinggal yang sudah rusak.

“.....banyak sekali masyarakat yang salah dalam penggunaan dana PKH tersebut, seharusnya untuk meningkatkan pendidikan anggora keluarga serta kesehatan anggota keluarga, namun ada yang digunakan untuk belanja kehidupan sehari-hari, kita tidak bisa mengawasi secara langsung penggunaannya, kita hanya bisa menghimbau masyarakat untuk menggunakannya secara bijak sesuai ketentuan yang telah ditetapkan..”

Kendala yang dihadapi oleh peserta $\mathrm{PKH}$, dalam hal pendidikan misalnya masih banyak anak sekolah yang duduk di bangku SD dan SMP enggan bersekolah dengan alasan tempat sekolah terlalu jauh untuk diakses dan kemalasan anak serta tidak ada motivasi orang tua juga lingkungan membuat anak malas sekolah. Kondisi ini sebagaimana disampaikan oleh Ibu Mardiana T selaku RTM Pulau Lebar:

“....masih banyak anak yang usia sekolah enggan sekolah, karena alasan mereka sekolahnya jauh, memang di Desa ini tidak ada SMP yang ada hanya SD itu pun lokasinya jauh, karena kurangnya motivasi yang diberikan orang tua, sehingga anak malas untuk bersekolah..."

Adapun kendala yang dialami oleh peserta PKH dalam melakukan kegiatan perbaikan kesehatan. Diantaranya adalah masyarakat enggan ke tempat pelayanan kesehatan, karena tempat pelayanan dipandang terlalu jauh dan mengakibatkan operasional menjadi mahal, seperti ongkos transportasi dan akses jalan yang rusak. Kemudian kepercayaan masyarakat masih mengandalkan dukun anak dalam melakukan pengobatan kesehatan dan cara-cara tradisional baik pengobatan untuk balita maupun untuk mengurus ibu-ibu hamil, ketimbang petugas kesehatan yang disediakan pemerintah, seperti puskesmas. 
Vol 1, No 1, Juni 2019, pp. 1-16

Persyaratan kesehatan yang sudah ditetapkan dalam protokol pelayanan kesehatan bagi peserta PKH belum dijalankan dengan baik. Seperti halnya kebiasaan yang dilakukan oleh beberapa penerima PKH dengan membeli obat warung jika anaknya sakit dan tidak membawanya ke Puskesmas yang sudah ditunjuk sebagai rujukan untuk pelayanan kesehatan.

Adapun kendala yang dialami oleh peserta PKH dalam melakukan kegiatan perbaikan kesehatan. Diantaranya adalah masyarakat enggan ke tempat pelayanan kesehatan, karena tempat pelayanan dipandang terlalu jauh dan mengakibatkan operasional menjadi mahal, seperti ongkos transportasi dan akses jalan yang rusak. Kemudian kepercayaan masyarakat masih mengandalkan dukun anak dalam melakukan pengobatan kesehatan dan cara-cara tradisional baik pengobatan untuk balita maupun untuk mengurus ibu-ibu hamil, ketimbang petugas kesehatan yang disediakan pemerintah, seperti puskesmas. Persyaratan kesehatan yang sudah ditetapkan dalam protokol pelayanan kesehatan bagi peserta $\mathrm{PKH}$ belum dijalankan dengan baik. Seperti halnya kebiasaan yang dilakukan oleh beberapa penerima PKH dengan membeli obat warung jika anaknya sakit dan tidak membawanya ke Puskesmas yang sudah ditunjuk sebagai rujukan untuk pelayanan kesehatan.

\section{Upaya Pemerintah Desa Pulau Lebar Kecamatan Tabir Barat dalam mengatasi hambatan pada program PKH dalam Meningkatkan Kesejahteraan Masyarakat}

\section{Meningkatkan Sosialisasi}

Pemerintah Desa Pulau Lebar berupaya melakukan sosialisasi bagi masyarakat untuk mengikuti setiap kegiatan pendampingan agar program PKH berjalan sesuai dengan harapan yang telah ditentukan oleh pemerintah. Dalam kejelasan dan konsistensi tujuan ini adalah bagaimana peraturan program $\mathrm{PKH}$ memberikan petunjuk-petunjuk yang cermat. Kemudian, program disusun secara jelas skala prioritasnya, untuk dilaksanakan oleh para pejabat pelaksana PKH dan pihak lainnya dalam pelaksanaan Program PKH di Kecamatan Tabir Barat. Acuan dalam implementasi program PKH di Kecamtan Tabir Barat yaitu mengacu pada aturan pedoman umum PKH tahun 2017.

2.Pemutakhiran Data Penerima PKH

Pemerintah Desa Pulau Lebar berupaya melakukan pemutakhiran data penerima PKH bersama dengan pendamping $\mathrm{PKH}$ dan perangkat desa, kejelasan aturan dalam pemilihan peserta $\mathrm{PKH}$, dimana target penerima bantuan PKH adalah rumah tangga sangat miskin (RTSM). Hal ini dipandang tidak ada kekeliruan. Penetapan rumah tangga sebagai RTSM dilakukan dengan menggunakan metodologi dan indikator yang transparan (dengan melihat pedoman umum PKH tahun 2017). Buku pedoman tersebut menyajikan informasi lebih rinci mengenai: penentuan RTSM; pemilihan lokasi pelaksanaan ujicoba; dan pemilihan peserta PKH.

Proses selanjutnya adalah pemutakhiran data. Merupakan perubahan sebagian atau seluruh data awal yang tercatat pada Master Data Base. Beberapa contoh perubahan informasi dari rumah tangga seperti perubahan tempat tinggal, kelahiran anggota keluarga, penarikan anak-anak dari program (kematian, keluar/pindah sekolah, dan sebagainya). Kemudian, masuknya anak-anak baru ke sekolah, ibu hamil, perbaikan nama atau dokumen-dokumen lainnya.

Pemutakhiran data dilaporkan oleh peserta di UPPKH Kecamatan. Pendamping PKH bekerjasama dengan ketua kelompok ibu peserta PKH akan memverifikasi perubahan data terkait. Dari proses mekanisme pemutakhiran data di atas, teridentifikasi terjadi pelanggaran, karena banyak diantara warga yang memenuhi criteria RTSM tidak masuk menjadi peserta PKH. Kondisi tersebut sebenarnya sudah jelas mekanismenya tetapi tidak dijalankan dengan baik, sehingga konsistensi dengan tujuan $\mathrm{PKH}$ terhambat dan tidak terwujud. 
Vol 1, No 1, Juni 2019, pp. 1-16

Adanya aturan penetapan Inclusion dan Exclusion Error, hal tersebut sebagai upaya memenuhi jumlah quota peserta PKH untuk suatu wilayah tertentu karena adanya peserta yang tidak memenuhi persyaratan tetapi masuk sebagai preserta PKH dan sebaliknya ada peserta yang memenuhi persyaratan peserta PKH tetapi tidak menjadi peserta PKH maka dilakukan penggantian sesuai quota desa yang bersangkutan, dengan mekanisme. Dalam pelaksanaan PKH di Kecamatan Tabir Barat hal ini tidak terjadi, dimana aturan sudah menjelaskan secara rinci tetapi konsistensi dengan tujuan PKH tidak terwujud dengan baik. Karena ada beberapa mekanisme yang dilanggar oleh petugas atau pendamping PKH.

Kejelasan aturan prosedur dalam pelaksanaan program PKH di Kecamatan Tabir Barat selanjutnya adalah dilakukan pertemuan awal, dimulai dengan pengiriman pemberitahuan terpilihnya RTSM sebagai peserta PKH, yang disertai format perbaikan data RTSM, pernyataan persetujuan memenuhi ketentuan PKH, dan undangan untuk menghadiri pertemuan awal oleh pihak Bank BRI. Pertemuan awal dikoordinasikan oleh UPPKH Kecamatan dengan mengundang petugas Puskesmas dan sekolah di kecamatan tersebut, hal ini berjalan sesuai prosedur.

3. Kepastian Jadwal Pembayaran

Selanjutnya prosedur pembayaran, dimana bantuan tunai hanya akan diberikan kepada RTSM yang telah terpilih sebagai peserta PKH dan mengikuti ketentuan yang diatur dalam program. Bukti kepesertaannya adalah kepemilikan kartu PKH yang tercantum nama ibu/wanita yang mengurus anak. Kartu PKH dikirim ke setiap peserta oleh pendamping sebelum pembayaran pertama dilakukan. Pembayaran bantuan dilakukan oleh PT Pos setiap tiga bulan pada tanggal yang ditentukan oleh masingmasing kantor pos untuk masing-masing desa/kelurahan.

Pembentukan kelompok ibu penerima bantuan. Setelah pembayaran pertama dilakukan, UPPKH Kecamatan memfasilitasi pertemuan kelompok ibu peserta PKH. Setiap 15-25 RTSM disarankan memiliki ketua kelompok yang berfungsi sebagai kontak bagi UPPKH untuk setiap kegiatan seperti antara lain sosialisasi, pelatihan, penyuluhan, penyelesaian masalah dan sebagainya selama program berlangsung. Ketua kelompok dipilih secara terbuka untuk menjaring kandidat yang secara sukarela memiliki komitmen tinggi untuk mensukseskan pelaksanaan PKH. Ketua kelompok terpilih tidak diperkenankan memungut bayaran apapun dari peserta PKH, tetapi dapat mengikuti kegiatan seperti mengikuti sosialisasi, pelatihan, penyuluhan dan sebagainya yang dilaksanakan oleh program.

4. Penangguhan atau Pembatalan Peserta

Penangguhan dan pembatalan peserta PKH. Penangguhan sementara berlaku apabila peserta PKH tidak memenuhi komitmen yang telah ditentukan untuk 1 kali siklus pembayaran ( 3 bulan berturutturut) dan peserta PKH tidak mengambil pembayaran untuk 1 kali siklus pembayaran ( 3 bulan berturutturut). Kemudian untuk pembatalan dapat terjadi apabila RTSM terbukti tidak layak sebagai peserta PKH, melalui antara lain pengaduan yang telah dibuktikan dan pengecekan berkala (spot check). Dalam 2 kali siklus pembayaran berturut-turut (6 bulan) RTSM tidak memenuhi komitmen tetapi melakukan klaim terhadap bantuan. RTSM yang telah dibatalkan kepesertaannya tidak dapat diajukan kembali sebagai penerima bantuan. Sejauh ini immpelemntasi program PKH di kecamatan belum ada yang dilakukan pembatalan

"Penggunaan pantun sebagai komuniasi politik yang serung disampaikana dalam orasi politik, dapat membuat si penyampai atau kandidat menjadi terkenal atau populer ditengah masyarakat, karena itu setiap bait-bait dalam pantun harus disusun sedemikian rupa sesuai dengan maksud dan tujuan dari kandidat itu sendiri. Penggunaan pantun juga dapat, meningkatkan konsenterasi audien dalam menyerap pesan-pesan yang disampaikan melalui bait-bait dalam pantun.” 
Vol 1, No 1, Juni 2019, pp. 1-16

\section{Kesimpulan}

Program PKH efektif dalam meningkatkan kesejahteraan masyarakat Desa Pulau Lebar Kecamatan Tabir Barat, dimana PKH adalah membantu mengurangi kemiskinan dengan cara meningkatkan kualitas sumber daya manusia pada kelompok masyarakat sangat miskin. Dalam jangka pendek, bantuan ini membantu mengurangi beban pengeluaran RTSM, sedangkan untuk jangka panjang, dengan mensyaratkan keluarga penerima untuk menyekolahkan anaknya, melakukan imunisasi balita, memeriksakan kandungan bagi ibu hamil, dan perbaikan gizi, diharapkan akan memutus rantai kemiskinan antar generasi.Terdapat hambatan program PKH dalam meningkatkan kesejahteraan masyarakat Desa Pulau Lebar Kecamatan Tabir Barat, diantaranya adalah: rendahnya partisipasi masyarakat, kendala teknis dalam proses pendataan penerima program $\mathrm{PKH}$, kendala teknis dalam pendampingan program $\mathrm{PKH}$, serta kendala teknis dalam penyaluran/pendistribusian dan penggunaan dana program PKH. Upaya Pemerintah Desa Pulau Lebar Kecamatan Tabir Barat dalam mengatasi hambatan pada program PKH dalam meningkatkan kesejahteraan masyarakat diantaranya; meningkatkan sosialisasi, pemutakhiran data penerima $\mathrm{PKH}$, kepastian jadwal pembayaran, penangguhan atau pembatalan peserta. 


\section{Daftar Pustaka}

[1] Abdul Halim, Akuntansi Keuangan Daerah, Penerbit Salemba Empat, Jakarta, 2004.

[2] Adi, Isbandi Rukminto. Kesejahteraan Sosial (Pekerjaan Sosial, Pembangunan. Sosial, dan kajian Pembangunan), Depok: Rajawali Pers

[3] Agung Kurniawan, Transformasi Pelayanan Publik. Pembaharuan, Yogyakarta, 2005.BKKBN. 2002. Buku Sumber untuk Advokasi

[4] Harbani Pasolong, Teori Administrasi Publik. : Alfabeta, Bandung, 2007.

[5] Hari Lubis dan Martani Huseini, Pengantar Teori Organisasi: Suatu Pendekatan Makro. Jakarta: Departemen Ilmu Administrasi, FISIP UI, 2002.

[6] JISIP: Jurnal Ilmu Sosial dan Ilmu Politik, ISSN. 2442-6962 Vol. 3, No. 1 (2014) Puslitbangkesos, Dampak Pada Rumah Tangga Sangat Miskin di Tujuh Provinsi.

[7] Jurnal Administrasi Publik (JAP), Vol.2, No12, Hal. 1-6

[8] Jurnal ISIP. Nomor 3 Tahun 2015, Vol. 2

[9] Kajian Kebijakan Publik. Volume 1 Nomor 1 Tahun 2016, 0-216

[10] Kementrian Sosial RI. 2012. Pedoman Umum Program Keluarga Harapan. Direktorat Jaminan Sosial

[11] Kuncoro, Mudrajad. 2004.Otonomi Dan Pembangunan Daerah Reformasi, Pencanaan, Star tegi, Dan Peluang. Jakarta: Erlangga.

[12] Lexi J, Moleong, Metodelogi Penelitian Kualitatif, (Bandung: PT. Remaja Rosda Karya, 2002)

[13] Lidiana (2014) Pengaruh dan Efektifitas Bantuan Program Keluarga Harapan (PKH) terhadap partisipasi pendidikan di Kecamatan Muara Tiga Kabupaten Pidie. Jurnal Ilmu Ekonomi. Volume 2, No. 2, Mei 2014. ISSN 2302-0172

[14] Lidiana (2014) Pengaruh dan Efektifitas Bantuan Program Keluarga Harapan (PKH) terhadap partisipasi pendidikan di Kecamatan Muara Tiga Kabupaten Pidie. Jurnal Ilmu Ekonomi. Volume 2, No. 2, Mei 2014. ISSN 2302-0172

[15] Mahmudi. Manajemen Kinerja Sektor Publik. UPP AMP YKPN, Yogyakarta, 2005.

[16] Nuggroho, Riant. 2009. Public Policy. Jakarta: Kelompok Gramedia.

[17] Peraturan Pemerintah (PP) Nomor 15 tahun 2010 tentang Percepatan Penanggulangan Kemiskinan

[18] Puslitbangkesos, Dampak Pada Rumah Tangga Sangat Miskin di Tujuh Provinsi.

[19] Soewarno Handayaningrat, Pengantar Studi Ilmu Administrasi dan Manajemen. Haji Masa gung, Jakarta, 1994.

[20] Sugiyono. 2010. Metode Penelitian Kuantitatif Kualitatif \& RND. Bandung : Alfabeta

[21] Suharto, Edi. 2011. Kebijakan Sosial Sebagai Kebijakn Publik. Alpabeta: Bandung

[22] Supriyono, Sistem Pengendalian Manajemen, Edisi Pertama, BPFE, Yogyakarta, 2000.

[23] Undang-Undang Nomor 11 Tahun 2009 Tentang Kesejahteraan Sosial 